\title{
СТОСУНКИ НАСТАВНИКА І ВЧИТЕЛЯ-ПОЧАТКІВЦЯ В ЯПОНСЬКОМУ КОНТЕКСТІ
}

\author{
Ольга Лученко \\ викладач японської мови \\ Харківський національний університет імені В.Н. Каразіна \\ м. Харків, Україна \\ http://orcid.org/0000-0002-2844-0441 \\ luchenkoolga@gmail.com
}

Анотація. У японському суспільстві міжособистісні стосунки розвиваються в межах глибинних культурно-історичних процесів. На побудову цих взаємин впливають традиційні поняття, які існують лише в Японії. Наставники відіграють значну роль у соціальнопсихологічній та професійній адаптації новопризначеного вчителя під час обов'язкової програми входження в професію, яка співпадає з випробувальним періодом. Успіх шкільної частини стажування значно залежить від міжособистісних стосунків, які сформуються між наставником і підопічним. У статті висвітлено унікальність формування їхніх взаємин під впливом складного культурного феномена «уті-сото». Метою статті є дослідження впливу культурно-історичного принципу «уті-сото» на стосунки наставника і молодого вчителя в Японії. У статті зроблено висновок, що вирішальним фактором продуктивності їхньої співпраці $є$ сприйняття новачка досвідченим учителем, як члена своєї групи «уті», що насамперед призводить до більш довірливого характеру спілкування i дає можливість попередити можливу дезадаптацію. У разі ставлення до початківця, як до стороннього із групи «сото», настанови досвідченого вчителя перестають бути консультативними і призводять до директивного характеру стосунків. Результати дослідження дають можливість подальшого творчого використання позитивного японського досвіду з професійної адаптації вчителів у перший рік після працевлаштування.

Ключові слова: наставництво; учитель-початківець; Японія; принцип «уті-сото».

Постановка проблеми в загальному вигляді. У Японії традиція підготовки «майстер - учень» має давнє коріння в різних галузях. Наставництво в Японії вважається ключем до успіху всієї системи освіти. Вивчення концептуальних підходів та організаційно-педагогічних засад педагогічного наставництва в Японії з урахуванням культурно-історичних особливостей дає можливість глибше зрозуміти його унікальність та ефективність і створює нові можливості для вдосконалення національної системи підтримки професійної адаптації вчителів-початківців.

Аналіз останніх досліджень i публікацій. Особливості роботи наставників з учителями-початківцями та їхню роль розглядали Т. Асада, Г. Вонг, Н. Морійосі, Д. Нохара, О. Озерська, А. Сакаі, Н. Сімахара та інші. Проблемі «уті» і «сото» приділяли увагу такі японські дослідники, як Р. Івата, Т. Йонеяма, К. Мідоока, Т. Накане, М. Осакі, Й. Сугімото та інші. Деякі вітчизняні й іноземні дослідники розглядали вплив цих ключових понять японської культури на японську мову (Т. Гуревич, Т. Корчагіна), економіку 
(Т. Кучай), бізнес-комунікацію (Ю. Стоногіна) тощо. Недостатньо досліджено вплив культурних особливостей подвійного підходу «уті-сото» в міжособистісних стосунках японців на природу педагогічного наставництва в Японії.

Формулювання цілей статті (постановка завдання). Мета статті дослідити вплив культурно-історичного принципу «уті-сото» на відносини наставника і молодого вчителя в Японії.

Результати дослідження. Давня практика наставництва, коли досвідчений дорослий надає підтримку й керівництво молодій, недосвідченій людині, існує як у західних, так і в азійських країнах. В Азії існує китайський ідеал Конфуція і японський термін «сенсей». Японці й китайці, так само як і населення інших азійських країн, мають колективну орієнтацію, коли цілі й результати групи мають першорядне значення. Поняття «колективізму» втілено в ідеалах наставництва [11, с. 13].

За словами В. Проннікова й І. Ладанова, у японців існує «особлива національна прихильність до групової взаємодії. Почуття належності до групи так сильно вкоренилось у психологію японців, що поза нею вони не уявляють свого існування. Таку групу може утворити сім'я, родичі, друзі тощо. На виробництві - це робоча група. Під час реалізації цілей японці здатні на великі жертви. Нерідко на догоду групи вони відмовляються від особистих благ, терплять негаразди» [5, с. $251-252]$.

М. Брайт наводить декілька культурних характеристик Японії, які призводять до сильних і тривалих емоційних зв'язків між особами і сприяють ефективному наставництву: 1) висока цінність безперервності; 2) важливість почуття обов'язку; 3) поняття поваги до старших; 4) концепція захисту молодших від невдач; 5) переважання робочих стосунків, заснованих на особистих, а не на договірних зв'язках; 6) високий рівень расової і гендерної узгодженості в японському наставництві [9, с. 334].

Схильність японців до належності до групи також має свій вплив. Орієнтація на сприйняття себе як члена групи відображена в японській системі виховання і практики початкової освіти, яка розроблена таким чином, щоб сприяти вихованню почуття взаємного обов'язку серед членів групи. Можливість мати наставника, до якого можна звернутися за порадою, сприяє соціальній, психологічній і професійній адаптації на першому етапі після працевлаштування.

Наставників, як і вчителів-предметників, призначає голова Ради з питань освіти (shidoshuji) за рекомендацією директорів шкіл, у яких розпочинають роботу початківці. Передбачається, що наставник повинен проводити індивідуальне керівництво й консультації для початківців. Багато дослідників підкреслюють визначну роль наставника в соціально-психологічній і професійній адаптації вчителя-початківця. Т. Асада вважає, що через те що період педагогічної практики під час навчання вчителів у ВНЗ Японії короткий (лише 4 тижні), наставництво відіграє вирішальну роль у початковій підготовці 
вчителів [8, с. 142]. На думку Н. Морійосі, саме наставник допомагає початківцю адаптуватися та пристосовуватися до нової посади [12, с. 421]. Д. Нохара зазначає, що наставник $є$ найбільш визначною особою в житті вчителя першого року призначення [13, с. 108]. Г. Вонг називає вчителя-наставника ключем до успіху в японській системі освіти [16, с. 381].

Приклади обов'язків, які виконують наставники (складені на основі урядової моделі, запропонованої Міністерством освіти, культури, спорту, науки і технології):

- складати річний план стажування;

- $\quad$ присвячувати 10 годин на тиждень для кожного новачка;

- спостерігати за уроками підопічного молодого вчителя (два рази на тиждень);

- надавати консультації для покращення викладання новачка $(2-3$ години на тиждень);

- уживати заходи щодо надання можливості вчителю-початківцю щотижня спостерігати уроки досвідчених учителів (2 години на тиждень);

- пропонувати допомогу в складанні плану занять;

- $\quad$ ознайомити з розподілом праці й обов'язків у школі.

Наставники допомагають початківцям із таких питань, як відвідування учнів, складання табелів успішності, організація шкільних обідів, дії в надзвичайних ситуаціях [14, с. 371].

Щоб зрозуміти природу наставництва, а саме роль наставника в Японії, потрібно подивитися на нього також із погляду виникнення стосунків «наставник - початківець». На формування міжособистісної комунікації й середовища взаємодії в колективі впливає унікальний принцип «уті-сото», який існує лише в Японії. За словами Т. Гуревич, «сприйняття світу через призму «утісото» є явищем психологічного характеру, воно пов'язане із соціокультурними традиціями і визначає сприйняття японцем навколишнього світу, людей і речей» [4, c. $105-106]$.

Японське суспільство належить до вертикального типу. Це означає, що типова для західних суспільств горизонтальна стратифікація в Японії суттєвим чином ускладнена наявністю меж, які розділяють суспільні шари на замкнені групи, що зміцнені стосунками патерналізму, - це становить принцип «іе» (тобто «вертикальні ієрархічні стосунки сімейного типу»). У рамках цієї структури діє принцип «уті-сото», згідно 3 яким відбувається розподіл на «своїх» та «чужинців» (зовнішній світ). Структура внутрішньо-групових зв'язків $\epsilon$ відображенням менталітету, культурної характеристики, а також являє собою одну із значних особливостей японської ідентичності - прагнення до найбільш ефективної на сьогоднішній момент соціальної організації [1, с. 34].

Усі соціальні стосунки в Японії - між особистістю й колективом, між індивідуумами, між колективами - будуються, виходячи з опозиції «свій чужий» $[2$, с. 26]. Розподіл на «своїх» (сім'я, друзі, колеги) і «чужинців» (незнайомці, сторонні люди, іноземці) є оригінальною особливістю японської 
ментальності й відображається в японській мові (граматиці та лексиці), бізнескомунікації та характеризує японське суспільство загалом. Це складний культурний феномен, який розподіляє і людей, і явища на дві категорії.

Принцип «уті-сото» розповсюджується на всі соціальні рівні. Однак, що дуже важливо, він не передбачає ворожості, а лише визначає належність до певної групи (до однієї сім’ї або компанії, а не до іншої) [7, с. 21]. Ці два поняття глибоко вбудовані в повсякденне життя і пронизують аспекти всіх взаємодій між індивідуумами і групами в японському суспільстві. «Уті» і «сото» представляють через взаємостосунки ототожнення з соціальною групою, сім'єю, бізнесом, школою. «Уті» - це внутрішне «я», ядро, частина, що належить цілому, а «сото» - це стороння людина, шанована, до якої ставляться 3 повагою, але яка не $\epsilon$ «своєю» частиною в соціальній групі «уті» [8, с. 139].

Як зазначає Т. Гуревич, опозиція уті-сото є «одним з основних критеріїв комунікації» для японців. А також «можна сказати, що японець сприймає співрозмовника, виходячи не лише з двомірної соціально-ієрархічної орієнтації, а ніби усвідомлюючи себе в тривимірному просторі: він позначає в своїй промові не лише своє соціально-вікове положення, але й зазначає, належить чи ні співрозмовник до тієї групи, до якої належить він сам» [3, с. 61].

М. Осакі переглянув поняття «уті-сото» в сучасному контексті. Уявлення про його класифікацію понять для сучасних умов Японії дає рис. 1 [17, с. 109].

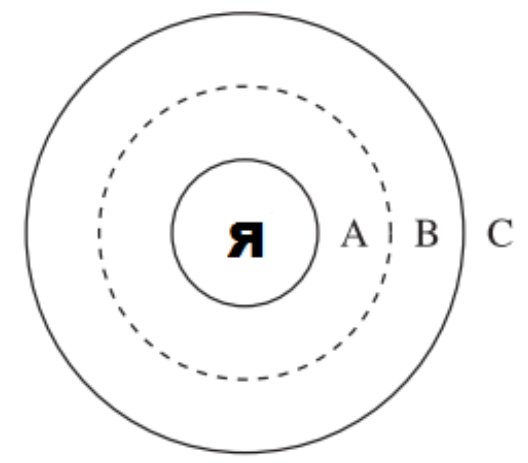

A: уті (суто внутрішня група)

B: уті (внутрішньо-зовнішня група)

$\mathrm{C}$ : сото

Рис. 1. Поняття «уті» $i$ «сото»у сучасній Японії

Він уважає, що поняття «уті» можна поділити на «суто внутрішню групу» і на «внутрішньо-зовнішню групу». До першої відносять сім'ю, близьких друзів і колег-приятелів. Друга група - це та, до якої належить сама людина: компанія, школа, клас. У цю групу можуть входити навіть знайомі зі спільного району проживання. До поняття «сото» дослідник, як і інші, відносить незнайомців, сторонніх людей, чужинців. Стосунки з цим прошарком людей він описує, як нещирі і прохолодні. М. Осакі робить висновок, що значення внутрішньої та зовнішньої групи в Японії, між якими раніше існувала «висока стіна», буде продовжувати змінюватись завдяки інтернаціоналізації, урбанізації, знижуванню народжуваності та змінам у спільнотах [17, с. 108 - 109].

Простір бізнес-комунікації у свідомості японця поділено лінією, у внутрішніх і зовнішніх межах якої він буде повністю змінювати свій стиль 
комунікації, і передусім свою власну мову - iї граматичну структуру. Передусім людина буде підкреслювати повагу до людей із поля «сото». Із погляду бізнесвідносин власна компанія і свої колеги завжди знаходяться в сфері «уті». Усі зовнішні компанії, зовнішні партнери, які б позитивні і тривалі взаємини не пов'язували вас, - це завжди «сото». У колективістському суспільстві ці два критерії японці застосовують насамперед для визначення стосунків взаємозалежності й повинності [6, с. 149].

Усвідомлення опозиції «свій - чужий» концентричними колами розходиться від індивідуума, при цьому залежно від обставин поле «чужий» може бути переведене в поле «свій» і навпаки [2, с. 28]. Лінія між «уті» та «сото» не $\epsilon$ статичною, тобто будь-яка людина може належати до однієї з двох груп залежно від соціальної ситуації. Зауважимо, що в спілкуванні, коли мова йде лише про представників прошарку «уті» (сім'я, родичі, друзі), вони насамперед будуть розподілені в тривимірному просторі. На формування міжособистісних стосунків впливає різного роду символіка й усталені вирази форм ввічливості. Японці змінюють свій стиль мови та зміст залежно від того, із ким вони мають справу: із представниками «уті» або «сото».

Сувора ієрархія, що існувала $з$ давніх-давен в японському суспільстві, була причиною появи складної системи ввічливості в японській мові. Протиставлення «свій - чужий», яке може змінюватися залежно від ситуації, має велике значення при виборі мовної форми. Мовна поведінка зі «своїми» і «чужими» кардинально різниться. Загальне уявлення про складність комунікації в японській мові, пов'язану з принципом «уті-сото», дає рис. 2, у якому на прикладі представників «уті» зображено типове розподілення, на основі якого буде обрано ту чи ту граматичну структуру речення. Варіативність стосунків між особами «уті», що приведе до змін форми дієслова в реченні, зображено стрілками різного кольору, залежно від того, на чию користь буде щось зроблено. Так, те, за що вдячний я або хтось із моєї групи «уті», зображено стрілкою чорного кольору, а те, за що повинен бути вдячний представник «сото», - білою. Отже, член родини може бути «уті» або «сото» залежно від інших дійових осіб конкретного речення. 


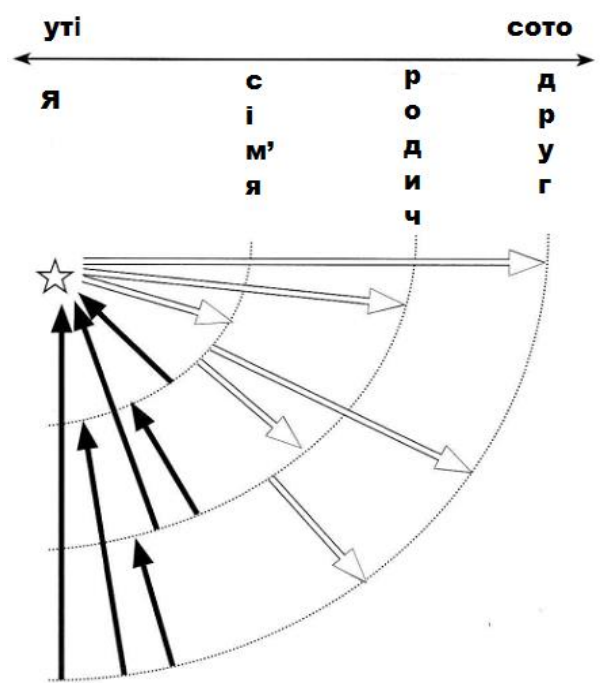

Рис. 2. Приклад взаємостосунків у групі «уті»

У Японії основний відсів кандидатів на посаду вчителя відбувається на етапі працевлаштування й обов'язкової програми входження у професію, яка співпадає з випробувальним терміном, після якого деякі вчителі не отримують постійну посаду. Тобто в перший рік офіційне призначення учителя-початківця не $\epsilon$ постійним, й у цей термін стосунки з колегами можуть розвиватися порізному.

На основі концепції «уті-сото» японський науковець Т. Асада досліджував, що означає наставництво в японському контексті: учнівство або спільне дослідження. Він зазначає, що в Японії новопризначені вчителі мають бути на рівних умовах з усіма іншими у школі. Так само, як і Н. Сімахара, він уважає, що майже всі японські вчителі сприймають рівноправність як «ненавчання». Однак менторські стосунки не можуть бути рівними, незважаючи на той факт, що наставництво триває лише рік. Фактично всі новопризначені вчителі мають спостерігати й копіювати досвідченого вчителя, як свою модель для наслідування. Так, дух рівності як культури японських вчителів перетворюється на учнівство, а не на спільне дослідження під час шкільного періоду стажування. Це сильніше відчутно в початковій школі, ніж у середній, бо кожен попередній клас - це закрита система зі своєю атмосферою, освітніми цілями, правилами тощо [8, с. 145,148$]$.

Як зауважує Т. Асада, шкільна частина стажування не завжди добре працює через відмінності в наставництві і його якості [8, с. 146]. Якщо наставник ставиться до свого підопічного, як до стороннього для цієї соціальної групи («сото»), він буде в невигідному становищі, бо його вважатимуть аутсайдером у вчительській професії [8, с. 149]. Те, як сприймає ментор підопічного: як такого, що знаходиться всередині («уті») соціальної структури школи чи за ії межами («сото»), - буде мати тривалий і помітний вплив на ставлення наставника $\mathrm{i}$, відповідно, на майбутне викладання підопічного [8, с. 152]. Т. Асада робить висновок, що «в ідеалі новопризначений учитель має усвідомити, що викладання - це процес навчання, для якого корисним $є$ підходи практичного дослідження 
для покращення навчання учнів. Чим більше можливостей для наставника i новопризначеного вчителя навчатись разом (спільне дослідження), тим вище імовірність того, що вони зможуть отримати знання щодо ефективного викладання. Близька співпраця будує відчуття взаєморозуміння, і початківець імовірніше буде прийнятий, як член вчительської спільноти («уті»)» [8, с. 154 $153]$.

Т. Асада під час дослідження виявив такі характеристики офіційного наставництва під час шкільної частини стажування:

1) наставник надає позитивний зворотній зв’язок підопічному впродовж одного року. Для початківця дуже важливо отримувати емоційну підтримку й бути визнаним своїм наставником як повноцінний учитель. Якщо в початківця виникають складнощі у викладанні, наставник надає емоційну підтримку, радше ніж демонструє, як навчати, пропонуючи альтернативні варіанти як форму інформаційної підтримки;

2) деякі наставники можуть показувати підопічному, як обдумувати викладання в рефлексивний спосіб, інші ж не розкривають їхнє рефлексивне мислення. В останньому випадку їх стосунки перетворюються на учнівство, тобто наставник часто вказує, що початківцю слід робити у викладанні;

3) було з'ясовано, що процес наставництва має три етапи: модель, тренер, критичний друг. Наставники спрямовують підопічних на те, щоб останні стали незалежними рефлективними практиками, і змінюють свою наставницьку роль iз моделювання рефлективного мислення як інструктора i співчуваючого мотиватора на критичного друга. Наставнику потрібно визнати початківця як вчителя і як члена внутрішньої групи «уті» [8, с. 148].

У Японії відкрита розмова про свої емоції та конфіденційні проблеми («хонне» - справжнє «я»), як правило, не відбувається з особами, які не належать до групи «уті» - найближчого оточення [15, с. 33]. Спілкування без напруги можливо лише зі «своїми». У розмові 3 «чужими» японці приховують свої справжні почуття й особисті судження («хонне») і говорять те, що належить говорити у відповідній ситуації («татемае» - соціально прийнятна думка) [4, c. 192]. Японці мають тенденцію не відкриватися членам не своєї групи, а 3 аутсайдером вони зазвичай ведуть ввічливі розмови про неважливі чи безпечні теми. Належність до «уті» або «сото» визначає глибину та стиль інформації, яку ви отримаєте від співрозмовника [10, с. 57]. Взаємодія між людьми однієї групи, як правило, є близькою та прямою, а особи, які належать до зовнішньої групи, отримують прохолодне ставлення, як до стороннього.

Отже, можна зробити висновок, що визнання наставником (як критичного друга) початківця як члена групи «уті» насамперед має вплив на відповідне ставлення до нього самого. Підопічний буде більш схильним відверто висловлювати свої проблеми і звертатися за порадою, що дасть наставнику можливість своєчасно діагностувати і попередити можливу дезадаптацію.

Висновки. Так, у Японії професійний розвиток учителя-початківця й успіх шкільної частини стажування загалом значною мірою залежить від здібностей 
наставника й особистих стосунків, які він зможе побудувати з початківцем. Оскільки наставників обирають із досвідчених учителів за рекомендацією директорів шкіл, це гарантує їхні високопрофесійні здібності. Одним із ключових факторів у міжособистісних стосунках «наставник - початківець» $\epsilon$ суто японський принцип «уті-сото». На ставлення ментора впливає його сприйняття вчителя-початківця, як члена своєї групи «уті», або як стороннього із групи «сото». Запорукою успіху програми входження в професію $\epsilon$ ставлення наставника до новачка, як до члена групи «уті», що передусім призводить до більш довірливого характеру спілкування («хонне») і допомагає початківцю вільно висловлюватися з приводу своїх професійних негараздів, звертатись за неформальною підтримкою або порадою. Дослідження японських учених (Н. Сімахара, А. Сакаї) свідчать про те, що більшість учителів-наставників у Японії насамперед бачать свою роль у якості консультанта, який допомагає молодим учителям, якщо ті звернулися до них за допомогою. Учені зазначають, що більшість наставників уважають менторське (директивне) ставлення неприпустимим і висловлюються за те, що стажерів потрібно мінімально контролювати і підтримувати їхню власну ініціативу.

Перспективою подальшого наукового дослідження $є$ аналіз архетипної природи наставництва і впливу традиційної культури викладання на стосунки наставників і вчителів-початківців у Японії.

\section{СПИСОК ВИКОРИСТАНИХ ДЖЕРЕЛ}

1. Грикун, Ю. О. (2007). Типи комунікації в сучасному японському соціальнофілософському дискурсі. Матеріали міжнародної наукової конференції «Дні науки філософського факультету». (С. 36). Київ: Київський університет.

2. Гуревич, Т. М. (2007). Японская грамматика как зеркало национального менталитета. Материалы ХІІ международной конферениии «Россия и Запад: диалог культур». (С. 26-32). Москва: МГУ. Взято с https://mgimo.ru/files/112285/114947.pdf

3. Гуревич, Т. М. (2005). Человек в японском лингвокультурном пространстве. Москва, Россия: МГИМО.

4. Алпатов, В. М., Гуревич, Т. М., Корчагина, Т. И., Нечаева, Л. Т. и Стругова, Е. В. (2013). Полвека в японоведении. Москва, Россия: Моногатари.

5. Пронников, В. А. и Ладанов, И. Д. (1985). Японџы (этнопсихологические очерки). Москва, Россия: Наука.

6. Стоногина, Ю. Б. (2012). Пространство и Время в японском бизнесе. Вестник МГИМО-Университета, 3, 148-152.

7. Лебедева, И. П., Маркарян, С. Б., Молодякова, Э. В., Матрусова, Т. Н. и Саркисов, К. О. (1996). Японский феномен. Москва, Россия: РИО Института Востоковедения PAH.

8. Asada, T. (2012). Mentoring: Apprenticeship or co-inquiry? In The SAGE Handbook of Mentoring and Coaching in Education (pp. 139-154). SAGE Publications Inc.. DOI: 10.4135/9781446247549.n10

9. Bright, M. (2005). Can Japanese mentoring enhance understanding of Western mentoring? Employee Relations, 27 (4), 325-339. DOI:10.1108/01425450510605679 
Стосунки наставника і вчителя-початківця в японському контексті

10. Lassila, E. T. (2017). Tensions in the relationships. Exploring Japanese beginning teachers' stories. Finland: University of Oulu. Retrieved from http://jultika.oulu.fi/files/isbn9789526214764.pdf

11. Lunsford, L. G. (2016). A Handbook for Managing Mentoring Programs: Starting, Supporting and Sustaining. NY: Routledge.

12. Moriyoshi, N. (1996). Teacher Preparation and Teachers' Lives in Japan. Contemporary Research in the United States, Germany, and Japan on Five Education Issues. H. W. Stevenson, SY. Lee, \& R. Nerison-Low (Ed.), (pp. 410-438). US: National Center for Educational Statistics.

13. Nohara, D. (1997). The Training Year: Teacher Induction in Japan. From Students of Teaching to Teacher of Students. Teacher Induction Around the Pacific Rim. J. Moskowitz, \& M. Stephens (Ed.), (pp. 95-130). Washington, DC: U.S. Department of Education.

14. Shimahara, N. K., \& Sakai, A. (2002). Teacher internship and culture of teaching in Japan. Education and training in Japan. T. Rohlen, \& C. Bjork (Ed.), (pp. 365-379). London: Routledge.

15. Sugimoto, Y. (2010). An introduction to Japanese society. New York: Cambridge University Press.

Retrieved

from https://polpemjepangsmjhiugm2015.files.wordpress.com/2015/09/yoshio_sugimoto-an-introduction -to-japanese-society.pdf

16. Wong, H. K., Britton, T., Ganser, T. (2005). What the World Can Teach Us About New Teacher Induction. Phi Delta Kappan, 86(5), 379-384. Retrieved from http://www.newteacher.com/pdf/PDK_Article_Jan05.pdf

17. 大崎 正瑠 (2008). 日本・韓国・中国における「ウチ」と「ソト」。東京経済大学 人文 自然科学論集,

125 , $105-127$.

Retrieved

from http://www.tku.ac.jp/kiyou/contents/hans/125/oosaki.pdf

\title{
ОТНОШЕНИЯ НАСТАВНИКА И НАЧИНАЮЩЕГО УЧИТЕЛЯ В ЯПОНСКОМ КОНТЕКСТЕ
}

\author{
Ольга Лученко \\ преподаватель японского языка \\ Харьковский национальный университет имени В.Н. Каразина \\ г. Харьков, Украина \\ http://orcid.org/0000-0002-2844-0441 \\ luchenkoolga@gmail.com
}

Аннотация. В японском обществе межличностные отношения развиваются в рамках глубинных культурно-исторических процессов. На построение этих отношений влияют традиционные понятия, которые существуют только в Японии. Наставники играют значительную роль в социально-психологической и профессиональной адаптации начинающего учителя во время обязательной программы вхождения в профессию, которая совпадает с испытательным периодом. Успех школьной части стажировки в значительной степени зависит от межличностных отношений, которые сформируются между наставником и подопечным. В статье освещается уникальность формирования их отношений под влиянием сложного культурного феномена «ути-сото». Целью статьи является исследование влияния культурно-исторического принципа «ути-сото» на отношения наставника и молодого учителя в Японии. В статье сделан вывод, что решающим фактором продуктивности их сотрудничества является восприятие новичка опытным учителем, как члена своей группы «ути», что в свою очередь приводит к более доверительному характеру общения и дает возможность предупредить возможную дезадаптацию. В случае отношения к начинающему, 
как к постороннему из группы «сото», наставления опытного учителя перестают быть консультативными и приводят к директивному характеру отношений. Результаты исследования дают возможность дальнейшего творческого использования положительного японского опыта по профессиональной адаптации учителей в первый год после трудоустройства.

Ключевые слова: наставничество; начинающий учитель; Япония; принцип «ути-сото».

\title{
MENTOR-NOVICE TEACHER RELATIONSHIPS IN JAPANESE CONTEXT
}

\author{
Olha Luchenko \\ Japanese Language Teacher \\ V. N. Karazin Kharkiv National University \\ Kharkiv, Ukraine \\ http://orcid.org/0000-0002-2844-0441 \\ luchenkoolga@gmail.com
}

\begin{abstract}
In Japanese society, interpersonal relationships develop within the framework of deep cultural and historical processes. The construction of these relationships is influenced by traditional concepts that exist only in Japan. Mentors play the most prominent role in the sociopsychological and professional adaptation of newly appointed teacher during the mandatory induction program that coincides with a probationary period. The success of the in-school part of the internship depends heavily on the personal relationships of mentors and novice teachers. The article highlights the uniqueness of the development of relations between a mentor and a novice teacher under the influence of a complex cultural phenomenon "uchi-soto".

The content of the mentors ' work with beginner teachers and their role were considered by T. Asada, N. Moriyoshi, D. Nohara, O. Ozerskaya, A. Sakai, N. Shimahara, G. Wong and others. The influence of cultural peculiarities on the nature of pedagogical mentoring in Japan has not been sufficiently studied. The paper aims to investigate the influence of the cultural-historical principle of "uchi-soto" on the relationships between a mentor and a young teacher in Japan. The article concludes that the decisive factor in the productivity of their cooperation is the mutual perception of the novice and the experienced teacher as members of uchi-group. In this case beginners tend to freely express the concerns and problems they have and the instructions of experienced teachers tend to be consultative. Otherwise the attitude towards beginners as an outsider from soto-group leads to the directive nature of the relationship and as the result the newly appointed teachers do not seek the informal support from their mentors and can experience problems in socio-psychological adjustment.

The results of the study provide an opportunity for further creative use of the positive Japanese experience on the professional adaptation of novice teachers.
\end{abstract}

Key words: mentoring; novice teacher; Japan; uchi-soto principle.

\section{REFERENCES (TRANSLATED AND TRANSLITERATED)}

1. Grykun, Y.O. (2007). Types of communication in the present Japanese social and philosophical discourse. Proceedings from International Conference "Dni nauky filosofskoho fakultetu”. (P. 36). Kyiv: Kyiv university.

2. Gurevich, T. M. (2007). Japanese grammar as a mirror of the national mentality. Proceedings from XII International Conference "Rossiya i Zapad: dialog kultur. (Pp. 26-32). Moscow: MGU. Retrieved from https://mgimo.ru/files/112285/114947.pdf

3. Gurevich, T. M. (2005). The man in the Japanese linguistic and cultural space. Moscow, Russia: MGIMO University.

Професіоналізм педагога: теоретичні й методичні аспекти. - Вип. 7. - Слов’янськ, 2018. 
4. Alpatov, V. M., Gurevich, T. M., Korchagina, T. I., Nechaeva, L. T., \& Strugova, E. V. (2013). Half a century of Japanese studies. Moscow, Russia: Monogotari.

5. Pronnikov, V. A., \& Ladanov I. D. (1985). The Japanese (ethnopsychological essays). Moscow, Russia: Nauka.

6. Stonogina, Y. B. (2012). Space and Time Are in Japanese Buisness. Vestnik MGIMOUniversiteta, 3, 148-152.

7. Lebedeva, I. P., Markaryan, S. B., Molodyakova, E. V. Matrusova, T. N., \& Sarkisov, K. O. (1996). The Japanese Phenomena. Moscow, Russia: RIO Instituta Vostokovedenija RAN. Retrieved from https://book.ivran.ru/f/yaponskij-fenomen-m-1996.pdf

8. Asada, T. (2012). Mentoring: Apprenticeship or co-inquiry? In The SAGE Handbook of Mentoring and Coaching in Education (pp. 139-154). SAGE Publications Inc.. DOI: 10.4135/9781446247549.n10

9. Bright, M. (2005). Can Japanese mentoring enhance understanding of Western mentoring? Employee Relations, 27 (4), 325-339. DOI:10.1108/01425450510605679

10. Lassila, E. T. (2017). Tensions in the relationships. Exploring Japanese beginning teachers' stories. Finland: University of Oulu. Retrieved from http://jultika.oulu.fi/files/isbn9789526214764.pdf

11. Lunsford, L. G. (2016). A Handbook for Managing Mentoring Programs: Starting, Supporting and Sustaining. NY: Routledge.

12. Moriyoshi, N. (1996). Teacher Preparation and Teachers' Lives in Japan. Contemporary Research in the United States, Germany, and Japan on Five Education Issues. H. W. Stevenson, SY. Lee, \& R. Nerison-Low (Ed.), (pp. 410-438). US: National Center for Educational Statistics.

13. Nohara, D. (1997). The Training Year: Teacher Induction in Japan. From Students of Teaching to Teacher of Students. Teacher Induction Around the Pacific Rim. J. Moskowitz, \& M. Stephens (Ed.), (pp. 95-130). Washington, DC: U.S. Department of Education.

14. Shimahara, N. K., \& Sakai, A. (2002). Teacher internship and culture of teaching in Japan. Education and training in Japan. T. Rohlen, \& C. Bjork (Ed.), (pp. 365-379). London: Routledge.

15. Sugimoto, Y. (2010). An introduction to Japanese society. New York: Cambridge University Press. Retrieved from https://polpemjepangsmjhiugm2015.files.wordpress.com/2015/09/yoshio_sugimoto-an-introduction -to-japanese-society.pdf

16. Wong, H. K., Britton, T., Ganser, T. (2005). What the World Can Teach Us About New Teacher Induction. Phi Delta Kappan, 86(5), 379-384. Retrieved from http://www.newteacher.com/pdf/PDK_Article Jan05.pdf

17. Osaki, M. (2008). A Comparative Study of "in-group"and "out-group"among Japan, Korea and China. Tokyo keizai daigaku jinbun shizen kagaku ronshu - Journal of Humanities and Natural Sciences, 125, 105-127. Retrieved from http://www.tku.ac.jp/kiyou/contents/hans/125/oosaki.pdf 